\title{
Bioszén hatása a talaj-növény-mikróba rendszerre: előnyök és aggályok - Szemle
}

\author{
Kocsis Tamás és BIRÓ Borbála
}

Budapesti Corvinus Egyetem, KTK Talajtan és Vízgazdálkodás Tanszék, Budapest

\section{Bevezetés}

A dél-amerikai Amazonas folyó közelében található közel egy méter vastagságú, fekete színű talajtípus szénben, kalciumban, magnéziumban, foszforban és mikroelemekben egyaránt gazdag. Becslések szerint Amazónia területének 10\%-át borítja az említett „Fekete Föld”, idegen néven „Terra Preta” talaj (VERHEIJEN et al., 2009). Termékenységének fő oka az az elhalt, termikus bomláson átesett biomassza-tömeg, amely a trópusi éghajlat alatt, oxigénmentes környezetben, hosszú ideig képes az adott talaj tulajdonságait kedvező irányba befolyásolni. A kimutatott pozitív hatások legfőbb okaként a talaj jobb levegőzöttségét, optimálisabb vízgazdálkodási tulajdonságait és az így közvetlenül és közvetve létrejött nagyobb mikrobiológiai aktivitást tartják, ami javítja a növények tápanyagellátását (RÉKÁSI \& UZINGER, 2015).

Az ilyen „szenesítési” folyamat során létrejött terméket nevezi a szakirodalom annak biológiai, természetes eredetére is utalva - „,biochar”-nak, bioszénnek (LEHMANN et al., 2009). A bioszén mesterséges előállítása különböző mezőgazdasági és ipari eredetű szerves „hulladék-anyagokból” és melléktermékekből is egyre perspektivikusabb, jelenleg már igen sokrétü előállítási mód és felhasználási javaslat körvonalazódik. A mesterséges előállítás módjától és a felhasznált alapanyagoktól függően megkülönböztetünk ,piroszén”-t és ,hidroszén”-t, melyet az ipari hulladék-anyagok nagy nyomáson és hőmérsékleten, levegő kizárásával és/vagy forró vízgőzzel történő szenesítésével állítanak elö. A talajokban történő alkalmazásra elsősorban a biológiai eredetü szén-termékek javasolhatók, mert összetételük elönyösebb a növénytáplálás szempontjából. Kérdésként merülnek fel azonban az alábbiak: A bioszén a talaj-növény-mikróba kapcsolatra kifejtett hatásai valóban minden esetben kedvezőek? Vannak alkalmazásának idő- és mennyiségi korlátai? Melyek a bioszén hatásait leginkább befolyásoló környezeti tényezők? A hatások közvetlenül vagy közvetve jelennek meg a talajok-fizikai kémiai tulajdonságain keresztül, vagy önállóan a talaj-növény-mikróba rendszerben?

Postai cím: BIRÓ BORBÁLA, Budapesti Corvinus Egyetem, KTK Talajtan és Vízgazdálkodás Tanszék, 1118 Budapest, Villányi út 29-43. E-mail: biro.borbala@gmail.com 
Ebben az összefoglaló munkában az volt a célunk, hogy azokat a bioszén alkalmazásával, felhasználásával kapcsolatos általános törvényszerüségeket áttekintsük és bemutatassuk, amelyek a bioszén mezögazdasági felhasználását talajtani szempontból alátámasztják vagy akár kizárhatják.

\section{A bioszén fogalma és elóállitása}

A bioszén az elhalt növényi és/vagy állati biomassza reduktív pirolízise (oxigénmentes közegben, magas hömérsékleten történő hevítés) során létrejött magas széntartalmú anyag. Szerkezeti tulajdonsága erősen függ a reduktív „égés” során elszenesedett kiindulási szerves anyagoktól és az előállítás körülményeitől (keletkezési hőmérséklet, hatóidő, stb.).

A bioszén az alapanyag szempontjából két nagy csoportra különíthető el:

1) A növényi hulladékból viszonylag alacsony - az irodalmi adatok szerint leggyakrabban $450-550^{\circ} \mathrm{C}$ hömérsékleten - készült nagy széntartalmú termékek, amelyek kiindulási anyaga rendszerint növényi maradványok, melléktermékek és/vagy állati trágyák. A kizárólag növényi eredetet megkülönböztetve a hulladékoktól, a minőség egyértelmü kifejezésére e termékeket PC (plant coal) biochar névvel is jelölhetik.

2) A kizárólag állati csontokból magas, rendszerint $600-650{ }^{\circ} \mathrm{C}$ hőmérsékleten elóállított Ca-foszfátban és főleg apatit ásványokban gazdag, lényegesen kisebb széntartalmú termékek elnevezése animal biochar (ABC).

A pirolízis folyamán a bioszénen kívül olajok és szintézisgázok is keletkeznek (1. táblázat).

1. táblázat

A különböző pirolízis eljárásokkal előállított szerves biomassza tömege és halmazállapota (IEA, 2006)

\begin{tabular}{|c|c|c|c|}
\hline \multirow[t]{2}{*}{$\stackrel{(1)}{\text { A pirolízis módja }}$} & $\begin{array}{c}\text { (2) } \\
\text { Folyadék } \\
\text { (bioolaj) }\end{array}$ & $\begin{array}{c}\text { (3) } \\
\text { Szilárd } \\
\text { (bioszén) }\end{array}$ & $\begin{array}{c}\text { G) } \\
\text { Gáz } \\
\text { (szintézisgáz) }\end{array}$ \\
\hline & \multicolumn{3}{|c|}{$\%$} \\
\hline $\begin{array}{l}\text { GYORS VIZES } \\
\text { Közepes hőmérséklet }\left(\sim 500{ }^{\circ} \mathrm{C}\right) \text {, } \\
\text { forró gőz, rövid idő }(2 \mathrm{~s}<) \text {, }\end{array}$ & $\begin{array}{l}75 \\
(25)\end{array}$ & 12 & 13 \\
\hline $\begin{array}{c}\text { LASSÚ VIZES } \\
\text { Alacsony hőmérséklet }\left(300-500{ }^{\circ} \mathrm{C}\right) \text {, forró gőz, } \\
\text { hosszú időtartam }\end{array}$ & $\begin{array}{c}50 \\
(50)\end{array}$ & 25 & 25 \\
\hline $\begin{array}{c}\text { LASSÚ HEVITÉSES } \\
\text { Alacsony hőmérséklet }\left(300-500{ }^{\circ} \mathrm{C}\right) \text {, } \\
\text { hosszú időtartam }\end{array}$ & $\begin{array}{c}30 \\
(70)\end{array}$ & 35 & 35 \\
\hline $\begin{array}{c}\text { GÁZOSÍTÓ HEVÍTÉSES } \\
\text { Magas hőmérséklet }\left(800^{\circ} \mathrm{C}<\right) \text {, hosszú időtartam }\end{array}$ & $*$ & 10 & 85 \\
\hline
\end{tabular}

Megjegyzés: zárójelben a víztartalom, \%; * 5\% kátrány- és 5\% víztartalom. 
A végtermék összetétele azonban az alapanyagoktól és az elöállítás módjától függően jelentős mértékben eltérő lehet.

A bioszén elóállítása egy adott létesítmény kapacitását és a kiindulási anyagokat is figyelembe véve elö-kísérletekkel optimalizálható, minősége bizonyos határok között állandóvá tehető. A keletkező bioszén termék tömege maximális, a kibocsátott gázok, gőzök, ipari víz és egyéb szennyezők mennyisége pedig minimális lehet (DEMIRBAS, 2006).

A technológiai optimalizálás hosszú folyamat, amit igen megnehezít a kiindulási anyagok közel sem állandó összetétele, vagy a technológiai rendszer a keletkező olajok miatt gyakori karbantartási igénye. A nehézségek miatt napjainkban már olyan „két-csatornás” elóállító eszközöket is kifejlesztettek, amelyekben az egyik oldali rész karbantartása alatt a másik egység üzemel - így az elóállítás folyamatos. Az eljárás gyakorlatba való átültetése azonban komoly költséghatékonysági problémákat vetett fel (GAUNT \& LEHMANN 2008). A keletkező bioszén mennyiségét és gyártástechnológiáját a rendelkezésre álló erőforrások (pl. víz, áram) ugyancsak befolyásolják.

\section{A biológiai aktivitást befolyásoló néhány fizikai-kémiai talajtulajdonság}

A „Terra Preta” talajok mind szerves anyag tartalomban, mind pedig ásványi anyagokban - az ezek közül is a legfontosabb NPK makroelemekben - jól ellátottak (2. táblázat). Ennek közvetlen és közvetett okai is vannak. A bioszén elöállitásánál leginkább növényi hulladékokat és állati trágyákat használnak fel, ami miatt a végtermék elemi összetétele arányos lehet az alapanyagok kezdeti összetételével. A folyamatban ugyanakkor a nitrogén a szénhez viszonyítva minimumba is kerülhet (RÉKÁSI \& UZINGER, 2015), amit a szük C:N arány jelez.

A víz és az ásványi talajalkotók magas koncentrációja a bioszén porózus szerkezetének, nagy adszorpciós képességének tulajdonítható. Felülete akár 800-5000 $\mathrm{mm} \cdot \mathrm{g}^{-1}$ is lehet. Porózus, levegös szerkezete közvetve hozzájárul a rendszerint igen nagy mikrobiális aktivitáshoz is.

A bioszénnek ezt a kedvező tulajdonságát használják ki azokban a szennyezett talajokban, ahol a környezeti (stressz) körülmények (levegötlenség, tápanyagok hiánya, kritikusan alacsony hőmérséklet) egyébként akadályoznák a remediációs folyamatot, így pl. a jégmentesítő propilén-glikol lebontásának az eredményességét (LiBISCH et al., 2012). FEIGL és munkatársai (2012) szintén a bioszén pozitív hatását emelik ki a talaj porozitására. A pórustérben a mikroorganizmusoknak nyújtott élőhely és a védő felszíni biofilm számos talajban, így különösen a kolloid-szegény homok-talajokban kulcsfontosságú.

Szintén pozitívan ható tényező a nagy széntartalom miatt kialakuló sötétebb talajszín, aminek következménye a talajhömérséklet közvetett emelkedése, megnövelve a mikrobiális csíraszám és aktivitás értékeket (GLASER, 2001). A fényelnyelöképesség javulására és a talajhőmérséklet emelkedésére kifejtett hatásokat főleg az északi, skandináv országok mezőgazdasági gyakorlatában lehet kellően hasznosítani. A bioszén felhasználással így kitolható például a kukoricatermesztés északi határa (OGUNTUNDE et al., 2004). 


\section{2. táblázat}

A kolumbiai „Terra Preta” és az azokkal szomszédos kontroll talajok főbb fizikai és kémiai tulajdonságai (LIANG et al., 2006; SOLOMON et al., 2007)

\begin{tabular}{|c|c|c|c|c|c|c|c|c|}
\hline \multirow{2}{*}{$\begin{array}{c}(1) \\
\text { Helyszín }\end{array}$} & \multirow{2}{*}{$\begin{array}{l}\text { (2) } \\
\text { Talaj }\end{array}$} & $\begin{array}{c}\text { (3) } \\
\text { Termö- } \\
\text { réteg }\end{array}$ & $\begin{array}{l}\text { (4) } \\
\text { Kor }\end{array}$ & $\begin{array}{c}(5) \\
\text { Agyag }\end{array}$ & $\mathrm{C}$ & $\mathrm{N}$ & \multirow{2}{*}{$\begin{array}{l}\mathrm{C}: \mathrm{N} \\
\text { arány }\end{array}$} & \multirow[t]{2}{*}{$\mathrm{pH}$} \\
\hline & & $\mathrm{cm}$ & év & $\%$ & \multicolumn{2}{|c|}{$\begin{array}{c}\mathrm{mg} \cdot \mathrm{g}^{-1} \\
\text { talaj }\end{array}$} & & \\
\hline \multirow{2}{*}{ Hatahara } & $\begin{array}{l}\text { Terra } \\
\text { Preta }\end{array}$ & $43-69$ & $\begin{array}{l}600- \\
1000\end{array}$ & 27,0 & 22,0 & 1,0 & 22 & 6,4 \\
\hline & Kontroll & $0-10$ & $\begin{array}{l}600- \\
1000\end{array}$ & 35,9 & 21,8 & 1,6 & 14 & 4,6 \\
\hline \multirow{2}{*}{$\begin{array}{l}\text { Lago } \\
\text { Grande }\end{array}$} & $\begin{array}{l}\text { Terra } \\
\text { Preta }\end{array}$ & $0-16$ & $\begin{array}{l}900- \\
1100\end{array}$ & 22,6 & 31,5 & 1,8 & 18 & 5,9 \\
\hline & Kontroll & $0-8$ & $\begin{array}{l}900- \\
1100\end{array}$ & 26,7 & 17,5 & 1,3 & 13 & 4,2 \\
\hline \multirow{2}{*}{ Acutuba } & $\begin{array}{l}\text { Terra } \\
\text { Preta }\end{array}$ & $48-83$ & $\begin{array}{c}2000- \\
3000 \\
\end{array}$ & 10,4 & 15,7 & 1,0 & 16 & 5,6 \\
\hline & Kontroll & $0-30$ & $\begin{array}{c}2000- \\
3000 \\
\end{array}$ & 8,5 & 15,4 & 0,8 & 19 & 4,7 \\
\hline \multirow{2}{*}{$\begin{array}{l}\text { Dona } \\
\text { Stella }\end{array}$} & $\begin{array}{l}\text { Terra } \\
\text { Preta }\end{array}$ & $\begin{array}{c}190- \\
210 \\
\end{array}$ & $\begin{array}{c}6700- \\
8700 \\
\end{array}$ & 0,3 & 16,5 & 1,1 & 15 & 5,0 \\
\hline & Kontroll & $0-12$ & $\begin{array}{l}6700- \\
8700\end{array}$ & 0,3 & 10,2 & 0,4 & 26 & 3,9 \\
\hline
\end{tabular}

\section{Bioszén és a talajok mikrobiológiai tulajdonságai}

Több kutatási eredmény is leírja a biológiai eredetü hulladékok és melléktermékek elszenesítésével mesterségesen létrehozott bioszén anyagok jótékony hatását a talaj termékenységére, biológiai aktivitásának növelésére, valamint a talajból származó üvegházhatású gázok (ÜHG) megkötésére is (LEHMANN, 2007; LAIRD, 2008; SOHI et al., 2009). Az ÜHG közül különösen a dinitrogén-oxid $\left(\mathrm{N}_{2} \mathrm{O}\right)$ és a metán $\left(\mathrm{CH}_{4}\right)$ mennyiségének csökkentését emelik ki (SPOKAS \& REICOSKY, 2009; Clough et al., 2010; SingH et al., 2010), de fontos tulajdonság a C adszorpció útján történő megkötése is (ZIMMERMAN et al., 2011).

A bioszén alkalmazása talajjavító anyagként leginkább savas kémhatású talajokhoz javasolt, mivel lúgosítja annak kémhatását és nagy kation-adszorpciós képességével javítja a talaj tápanyagmegtartó képességét - ezáltal előnyösen befolyásolja a talajok termékenységét (LiANG et al., 2006).

A talajokra vonatkozó hatások összefoglalását és a megfelelö következtetések levonását ugyanakkor nehezíti a leírt kísérletek és helyszínek, valamint a vizsgálati módszerek sokszínüsége. Az eredmények több esetben ellentmondásosak, vagy hiányosak, esetleg csak egy-egy tényezőt emelnek ki egy sok-tényezős rendszerből.

A bioszén alkalmazásának feltétele erősen függ az adott talaj tulajdonságaitól, a környezeti körülményektöl, az alapanyagtól, a dózistól és még számos egyéb 
biotikus és abiotikus tényezőtől. A bioszén célzott alkalmazásával a talajbióta közösségekben olyan változások következhetnek be, amelyek érdeklődésre, de aggodalomra is okot adhatnak. A mikrobiális közösség mennyiségi alakulásánál nem csak a növény növekedése szempontjából kedvező, hanem a talajeredetü, az élelmiszerek minősége és az élelmiszerbiztonság szempontjából potenciális patogénnek tekinthető kórokozók is felszaporodhatnak (BECZNER et al., 2004). Talajvédelmi szempontból az ilyen irányú kutatások igen nagy jelentőségüek, mivel a talaj mikrobiológiai közösségei kihatnak annak funkcióira és a talajra, mint ökoszisztémára egyaránt (Kotroczó et al., 2009, 2014; SzILI-KovÁCS et al., 2011a; KoCsis et al., 2015).

A működőképességre ható tulajdonság például a szerkezet és stabilitás, a levegőzöttség, a tápanyagkörforgás, a vízháztartás valamint a C-megkötés (TóTH et al., 2013). Ide sorolható a talajoknak patogénekkel szembeni szupresszív vagy receptív tulajdonsága, amelyhez a bioszén pozitív és negatív módon képes hozzájárulni.

A bioszén pozitív hatását a talaj mikrobiális biomassza tömegére a legkülönbözőbb talajbiológiai módszerekkel végzett vizsgálatok eredményei is igazolták már. Ezek között a legismertebbek: a közösségi nukleinsav analízis (GROSSMAN et al., 2010; JIN, 2010); a kitenyésztéses és/vagy klasszikus telepszámlálásos eljárások (O’NEILL et al. 2009); a szubsztrát indukált légzés vizsgálatok (ZACKRISSON et al., 1996; STEINER et al., 2004; WARDLE et al., 2008; KOLB et al., 2009); a fumigációs extrakciós módszer (JIN, 2010; LIANG et al., 2010); a foszfolipid zsírsav analízis (BIRK et al., 2009) és a festődő részecskék mikroszkópos vizsgálatai (PIETIKÄINEN et al., 2000; WARNOCK et al., 2007; JIN, 2010).

PIETIKÄINEN és munkatársai (2000) illetve STEINER és munkatársai (2004) megállapították, hogy a bioszénnel kezelt talajokban a mikrobák reprodukciós rátája nő. A mikrobiális aktivitást közvetve befolyásolta az is, hogy a biológiai bomlás során képződő metán - mint energiaforrás - mennyisége szintén több lett a hozzáadott bioszén hatására. KUMAR és munkatársai (1987) közvetett hatásként az anaerob és a cellulózlebontó baktériumok mennyiségének növekedését is megfigyelték.

$\mathrm{Az}$ egyes fiziológiai csoportokon belül a növényprodukció és -egészség, az élelmiszerek minősége és az élelmiszerbiztonság szempontjából is sokféle típusú és funkciójú mikroba előfordulhat. A mikrobiális biomassza tömeggyarapodása a bioszén hatására általánosan tapasztalt jelenség (Kocsis et al., 2015), de annak mértékét és elérhető maximumát a vizsgált mikrobacsoportok ökofiziológiai tulajdonságai jelentős mértékben meghatározzák, pl. stresszterhelt szikes talajokon is (BIRÓ et al., 2005). A bioszén a nagy széntartalmú cukrokhoz hasonlóan immobilizálja a talaj könnyen felvehető N-tartalmát és ezzel a környezeti restaurációs eljárásoknak szintén egyik eredményes eszköze lehet (SzILI-KovÁCs et al., 2011b). Az ilyen irányú felhasználásnak is van perspektívája, bár erre vonatkozóan ismereteink még meglehetősen hiányosak.

A talaj-növény rendszerekben leggyakrabban a rhizoszféra mikrobiológiai tulajdonságait vizsgálják (3. táblázat). JIN (2010) és TRESEDER és AlLEN (2002) úgy találta, hogy a rhizoszférába juttatott bioszén növeli a mikrobák mennyiségét egy bolygatatlan, nem kezelt talajhoz viszonyítva. 
A tapasztalatok általánosítását azonban nehezíti, hogy ennek a hatásnak GRABER és munkatársai az ellenkezojjéről is beszámoltak (2010), utalva az alkalmazás erős dózisfüggőségére is.

A mikroszimbiontákkal kapcsolatban igazolást nyert, hogy az arbuszkuláris(AM) és az ektomikorrhizák (EM) jelenlétét és infekcióját is pozitívan befolyásolja a bioszén jelenléte (WARNOCK et al., 2007). Mind az ektomikorrhiza képződés sebessége, mind a gyökérkolonizáció mértéke nőtt (157\%-al) a vörösfenyő palánták gyökerein (MAKOTO et al., 2010).

A búza rhizoszférájában az AM kolonizáció 40\%-al lett nagyobb két év bioszén alkalmazás után (SOLAIMAN et al., 2010). SOlAimAN és munkatársai (2010) A faültetvényhez adagolt $6 \mathrm{t} \cdot \mathrm{ha}^{-1}$ mennyiségü bioszén hatására $20 \%$-os növekedést tapasztaltak a mikorrhiza kolonizációban. Nem ismert azonban, hogy a gombák mennyiségét és a gyökéren túlnyúló extraradikális hifatömeget hogyan és milyen mértékben befolyásolja a hozzáadott bioszén.

A porózus anyag leginkább a belső pórustereivel tud védelmet nyújtani a fizikai sérülésektöl, amit például a talaj tömörödése, vagy a talajfauna mikrobiális táplálkozása okoz. A bioszén egyik fontos hatása ezért a belsejében található mikroorganizmusok tényleges felszíni védelme, ami elsősorban azok kiszáradásra való érzékenysége miatt meghatározó jelentőségü (WARNOCK et al., 2007).

A bioszén hatása kedvező a talajban keletkező gázok, így például a $\mathrm{CO}_{2}$ felületi megkötődésére is. Ezek az indirekt mechanizmusok befolyással vannak a talajok mikrobiológiai aktivitására és a mikrobacsoportok összetételére is (ELMER \& PignATELlo, 2011; LiBISCH et al., 2012; BIRÓ et al., 2013), hatásuk azonban erösen széntartalom függő.

\section{3. táblázat}

A bioszénnel ellátott talajok tulajdonságai és hatásuk a talajok föbb szimbionta mikroorganizmus csoportjaira (LEHMANN et al., 2011 alapján).

\begin{tabular}{|l|c|c|c|c|}
\hline \multicolumn{1}{|c|}{$\begin{array}{c}(1) \\
\text { Mechanizmus, hatás }\end{array}$} & Rhizobium & $\begin{array}{c}(2) \\
\text { Baktériumok }\end{array}$ & Mikorrhiza & $\begin{array}{c}(3) \\
\text { Gombák }\end{array}$ \\
\hline Talajeredetü kórokozók elleni & 0 & + & + & + \\
védelem & + & + & + & $?$ \\
Hidratáltság & + & + & - & - \\
P-, Ca-, Mg-, K-ellátottság & + & + & - & $?$ \\
Mikroelem-ellátottság & + & + & 0 & 0 \\
pH-növekedés & - & - & 0 & $0 /-$ \\
pH-csökkenés & $? /-$ & $?$ & $?$ & $?$ \\
Szorpciós jelátviteli vegyületek & - & $+/-$ & 0 & 0 \\
N-ellátottság & 0 & + & 0 & 0 \\
Mikroorganizmusok & + & + & $?$ & $?$ \\
szorpciója & Biofilm képződés & & + & 0 \\
\hline
\end{tabular}

Megjegyzés: + pozitív hatás; - negatív hatás; 0 nincs változás; ? nem ismert reakció 
RILLING (2010) úgy találta, hogy a hidrotermális úton előállított aktív szén a „hidrochar” tulajdonságai jelentősen eltérnek a pirolizált változattól. A hidrotermás szén a nagyobb víztartalom miatt inkább stimulálja az AM gombaspórák csírázását és populációját a talajban. A növényekben ezzel szemben a hidrotermás szénnél csökkenhet az AM kolonizáció a kialakult jobb fizikai-kémiai talajállapot miatt ami a végül a szimbiózist szükségtelenné teszi (GAUR \& ADHOLEYA 2000; BIRK et al., 2009; WARNOCK et al., 2010).

A nagy foszfortartalmú, csont eredetủ bioszén alkalmazása mellett az AMszimbiózis csökken (CORBIN et al., 2003; COVACEVICH et al., 2006; GRYNDLER et al., 2006; SCHMIDT et al., 2010). Az élő és közvetlen kapcsolatot biztosító hasznos mikorrhiza gombák alapvető szerepe - a foszfor- és egyéb elemfelvételt javító tulajdonságaik, vagy akár a stressz-puffer képességük - egyaránt csökkenhet a különböző bioszén termékek alkalmazásával.

A bioszén közvetlen negatív hatásait ki lehet mutatni a nagy só vagy nehézfém tartalmú talajokon is, amelyek a kialakult rossz kémiai tulajdonságaik miatt gátolják a talaj/rhizoszféra kapcsolat kialakulását és müködőképességét (KILLHAM, 1985; AzCóN et al., 2009). A bioszén felületétől és porozitásától függően, szorpciós úton megkötheti nem csak a szennyező anyagokat, hanem a növénytáplálás szempontjából fontos szerves tápanyagokat is. Ezek hiánya a stressz-terhelt talajban kiemelt jelentőségü lehet (PIETIKÄINEN et al., 2000; CHAN \& XU, 2009).

A korábbi eredmények szerint, ha nincs bioszén, akkor a környezeti stressz hatására szikes-, vagy nehézfém-szennyezett talajokon nem a csökkenés, hanem éppen ellenkezőleg a mikorrhiza gombák mennyiségi növekedése, a szimbiotikus kapcsolat javulása figyelhető meg. Ezek az eredmények jelzik tehát a szimbionta kapcsolat érzékenységét. A bioszén alkalmazása ilyen talajokon meggondolandó, megfelelő szaktudást igénylő (BIRÓ et al., 2009, FüZY et al., 2008).

A bioszén kedvező hatását csökkentheti a hozzáadott műtrágyák adagolásával előidézett túlzott tápanyagtöbblet is, ami közvetve még a növénytáplálást segítő mikrobák szaporodási sebességének mérséklését is kiválthatja (STEINER et al., 2009).

BLACKWELL és munkatársai (2010) az AM kolonizáció javulását csak a legkisebb mennyiségü „starter” mütrágya-adagolás mellett figyelte meg. BIRó (2002) tapasztalata szerint a szimbiózist segíteni képes $\mathrm{N}$-dózis egy alacsony $(1,5 \%)$ humusztartalmú talajon $45 \mathrm{~kg} \mathrm{~N}$ és csak $120 \mathrm{~kg}$ P mútrágya hatóanyag $\cdot{ }^{-1}{ }^{-1}$-nak feleltethető meg. Az ennél nagyobb mütrágya adagok a szimbionta működőképesség és a gazdaságos biológiai $\mathrm{N}_{2}$-kötés többszörös visszaesését váltották ki.

A mikorrhiza gombák tápanyagfelvételt segítő hatását leginkább a P-tartalmú mütrágyák mérsékelték, a N-tartalmúak nem. A pillangós növények kezdeti fejlődési szakaszában a szimbiotikus kapcsolatra képes nitrogénkötő Rhizobium baktériumoknál OGAWA \& OKIMORI (2010) ezzel ellentétes eredményt mutattak ki. Nitrogén- és/vagy foszformütrágya hozzáadásával a szimbiózis ki sem alakul, vagy ha igen, akkor azt később leépíti a gazdanövény. Meglévő szimbiózisnál a müködést jelző és biztosító arbuszkulum gazdagság a növény igénye szerint akár nyolc nap alatt visszacsökkenhet, vagy ismét ki is alakulhat (FüZY et al., 2008). 
Azonos környezeti feltételek mellett a mikrobiális biomassza alakulása növekvő tendenciát mutat a pH 3,7-től a 8,3-ig növekvő tartományban (ACIEGO \& BROOKES, 2008; BIRÓ, et al., 2012; FEKETE et al., 2012). A gombák és a baktériumok azonban különböző módon reagálnak a pH változásaira. A baktériumok száma tömegesen növekszik 7-es pH környékén, a gombák állománya nem változik a semleges értékeknél és mennyiségük csökken a lúgosabb pH-tartományban (ROUSK et al., 2009). Hasonló összefüggést figyeltek meg a Rhizobiumokkal infektált hüvelyes növényeknél is (ANGELINI et al., 2003).

A bioszén anyaga, előállítási hőmérséklete és a kijuttatott mennyisége függvényében a talaj kémhatása elérhet $\mathrm{pH}$ 4-nél kisebb és $\mathrm{pH}$ 12-nél nagyobb értéket is (LeHMANN, 2007; CHAN \& XU, 2009). A mikrobiális biomassza alakulását befolyásoló fontos tényező a bioszén talajba kerülését követő utólagos oxidációjának mértéke (CHENG et al., 2006).

Kevés közvetlen bizonyíték áll rendelkezésre arról, hogy a bioszén fizikaikémiai adszorpciós tulajdonságai miatt - a növényi tápanyagok fokozottabb felvehetöségén keresztül (közvetlen hatás) - vagy a bioszén pórusaiban nagyobb menynyiségben megtelepedő mikroorganizmusok (közvetett hatás) okozzák-e a növénynövekedésben kimutatott kezdeti kedvező hatásokat. A jövőben várható a mikrobiológiai oltóanyagok és a bioszén kombinált alkalmazása, tovább növelve a biotrágyák, növénykondícionálók és egyéb biokontroll ágensek vagy élő és élettelen bioeffektorok mezőgazdasági és környezetvédelmi térhódítását (WARNOCK et al., 2010).

\section{A bioszén és a talajok termékenysége röviden}

Az eddigi kutatási eredmények többsége igazolta a bioszén kedvező hatását a talajok termőképességének a javulására (LEHMANN et al., 2003; BLACKWELL et al., 2009). A szerzők az eddigi, különösen a rövid-távú vizsgálatok $90 \%$-ában jelezték a bioszén termésnövekedést indukáló hatását. LEHMANN és RONDON 2006-os kutatása szerint a termés 20-220\%-al nött a bioszén mennyiségével arányosan.

BLACKWELL (2009) véleménye szerint azonban ez a megállapítás csak az intenzív szántóföldi kultúrára vonatkozik és nincs adat más, pl. biotermesztésü területekre.

MAJOR (2010) a kukorica állomány szója felülvetéssel történö termésnövekedését és tápanyag utánpótlását vizsgálta 2003 és 2006 között. A növényi bioszenet 8 és $20 \mathrm{t} \cdot \mathrm{ha}^{-1}$ mennyiségben alkalmazta. A termés az első évben nem, de az utána következő években a $20 \mathrm{t} \cdot \mathrm{ha}^{-1}$ bioszénnel kezelt parcellákban 28, 30 és $140 \%$-os növekedést mutatott (1. ábra). A hatás a jobb tápanyagfelvételnek és a talajok $77-$ 320\%-al nagyobb Ca- és Mg-tartalmának tulajdonítható a bioszénnel javított parcellákban. A dózishatásra és a jelenlegi ismereteink hiányosságaira utaló jel ugyanakkor a további években megnyilvánuló mérsékeltebb termésnövekedés, ami a tartamhatás jellegủ vizsgálatok fontosságára és a folyamatos talaj-monitoring szükségességére hívja fel a figyelmet. 


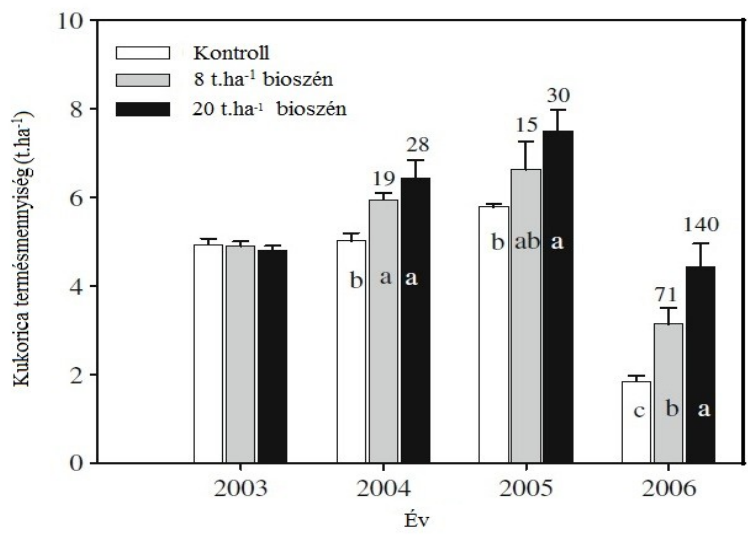

1. ábra

A bioszén hatása a kukorica terméseredményére. A hozamnövekedést \%-ban fejeztük ki, az oszlopon lévő betük a szignifikáns $(p<0,05)$ különbségeket jelzik (MAJOR et al., 2010).

\section{Összefoglalás}

A rendelkezésre álló szakirodalmi hivatkozások a bioszén széleskörü felhasználási lehetöségeit jelzik a talaj-növény-mikroba kölcsönhatás alakulására. A bioszén kedvezően befolyásolhatja a talajok fizikai-kémiai tulajdonságait, pl. vízháztartását, agyag- és szervesanyag-tartalmát, a kémhatását, a N- és P-tartalmát, a mezo- és mikroelemek mennyiségét és porózus szerkezete miatt annak levegőzöttségét, az oxigéntartalmát vagy az oxigén relatív mennyiségét a pórustérben.

A növénytáplálásra kifejtett kedvező hatások közvetlenül és közvetve is megnyilvánulhatnak. A mikroorganizmusok intenzívebb szaporodása a bioszénnel kezelt területeken az irodalmi adatok alapján jól megalapozottnak tekinthetö. A bioszén kiszáradástól való felületi védelmet, oxigéndúsabb környezetet, és adszorbeált szerves anyagokat is jelent a mikroorganizmusoknak; gombáknak és baktériumoknak egyaránt. A jobb mikrobiális ellátottság eléréséhez a talaj a fizikai-kémiai tulajdonságok mellett kedvező hömérséklet és a kémhatás is hozzájárul.

A bioszén növénytermesztési technológiákba történő integrálásának eredményei így leginkább rövidtávon, de termésnövekedésről adnak számot. A növénytermesztés szempontjából hasznos mikroszimbionta nitrogénkötő baktériumok valamint a foszformobilizáló mikorrhiza gombák mennyisége és aktivitása ugyanakkor erősen dózis és termékfüggő. A növény-mikroba szimbiózis hatékonysága a leginkább szükséges és kritikus környezeti stressz-körülmények között rosszabbodhat. Aggódásra ad okot a helytelenül használt nagy bioszén-dózisok tápanyag- és/vagy vízlekötő tulajdonsága és nem utolsó sorban a talajeredetủ patogén mikroorganizmusok fokozott felszaporodási lehetősége is. 
A bioszén tehát olyan értékes eszköz lehet a kezünkben, aminek előnyeit csak a megfelelö talajfizikai, -kémiai és -biológiai vizsgálatokra alapozottan, odafigyeléssel és kellő szakmai ismeretekkel együtt használhatunk ki jól és biztonságosan.

A kutatásokat a „Biochar szilárd mikrobiológiai hordozó és EM előállításának, felhasználási technológiájának kísérleti fejlesztése a szerves trágya kezelésben, az állati takarmányozásban és a talajminőség javításában" (Piac-13-1-2013-0274) és az EU-KP7 „Development of alternative fertilization systems by use of bioeffectors in European agriculture" (CA 312117) projektek biztosítják.

Kulcsszavak: Terra Preta, biochar, bioszén, talajmikrobák, szimbiózis

\section{Irodalom}

ACIEGO, J. C. \& BRoOKes, P. C., 2008. Relationships between soil pH and microbial properties in UK arable soil. Soil Biol. Biochem. 40. 1856-1861.

ANGELINI, J., CASTRO, S. \& FABRA, A., 2003. Alterations in root colonization and nodC gene induction in the peanut-rhizobia interaction under acidic conditions. Plant Physiol. Biochem. 41. 289-294.

Azcón, R., Medina, A., Roldán, A., Biró, B. \& Vivas, A., 2009. Significance of treated agrowaste residue and autochthonous inoculates (arbuscular mycorrhizal fungi and Bacillus cereus) on bacterial community and phytoextraction to remediate soils contaminated with heavy metals. Chemosphere. 75. 327-334.

BeCZner J., Biró B., KorbÁsz M. \& JANKó Sz., 2004. A talaj mint a növényi eredetú élelmiszerek mikrobás szennyezettségének a forrása. Konzervújság. 3. 81-84.

Birk, J. J., Steiner, C., Teixeira, W. C., Zech, W. \& Glaser, B., 2009. Microbial response to charcoal amendments and fertilization of a highly weathered tropical soil. In: Amazonian Dark Earths: Wim Sombroek's Vision. (Eds.: WoodS, W.I., Teixeira, W.G., Lehmann, J., Steiner, C., WinklerPrins, A.M.G.A., ReBellato, L.) 309-324. Springer. Berlin.

BIRÓ B., 2002. Talaj és rhizobiológiai eszközökkel a fenntartható növénytermesztés és környezetminőség szolgálatában. Acta Agronom. Hung. 50. 77-85.

BIRÓ B., VILLÁNYI I., FÜZY A. \& NAÁR Z., 2005. Baktériumok és gombák kolonizációja génmódosított (Bt-) és izogénes és kontroll kukorica rhizoszférájában. Agrokémia, Talajtan 54. 189-203.

BIRÓ, I., NÉMETH, T. \& TAKÁCS, T., 2009. Changes of parameters of infectivity and efficiency of different Glomus mosseae AM fungi strains in Cadmium-loaded soils. Comm. Soil Sci. Plant Anal. 40. 227-239.

BIRÓ, B., DOMONKOS, M. \& KISS, E., 2012. Cathabolic FDA microbiological activity as site-dependent monitoring tool in soils of an industrial town. Internat. Rev. Appl. Sci. Engeneer. 3. 1-6.

Biró, B., Horváth, N., Matics, H., Domonkos, M. \& Malov, X., 2013. Enhanced degradation of deicing fluids in soils and soil-plant systems by improving soil nutrient status and quality. In: Proc. of 12th Alps-Adria Sci. Workshop Opatija, Doberdò, Venezia (Croatia, Italy), Növénytermelés. 62. 393-396. 
Blackwell, P., Riethmuller, G. \& Collins, M., 2009. Biochar application to soil. In: Biochar for environmental management: science and technology. (Eds.: LEHMANN, J. \& JOSEPH, S.) 207-226. Earthscan. London.

Blackwell, P., Krull, E., Butler, G., Herbert, A. \& Solaiman, Z., 2010. Effect of banded biochar on dryland wheat production and fertilizer use in SW Australia: an agronomic and economic perspective. Austral. J. Soil Res. 48. 531-545.

CHAN, K. Y. \& XU, Z., 2009. Biochar: nutrient properties and their enhancement. In: Biochar for Environmental Management: Science and Technology (Eds.: LEHMANN, J. \& JoSEPH, S.) 67-84. Earthscan. London.

Cheng, C. H., Lehmann, J., Thies, J. E., Burton, S. D. \& Engelhard, M. H., 2006. Oxidation of black carbon by biotic and abiotic processes. Org. Geochem. 37. 1477-1488.

Clough, T. J., Bertram, J. E., Ray, J. L., Condron, L. M., O’Callaghan, M., SHERLOCK, R. R. \& WELLS, N. S., 2010. Unweathered wood biochar impact on nitrous oxide emissions from a bovine-urine-amended pasture soil. Soil Sci. Soc. America J. 74. 852-860.

Covacevich, F., Marino, M. A, EcheverriA, H. E., 2006. The phosphorus source determines the arbuscular mycorrhizal potential and native mycorrhizal colonization of tall fescue and wheatgrass. Eur. J. Soil Biol. 42.127-138.

Corbin, J. D., AVIS, P. G. \& WilbUR, R. B., 2003. The role of phosphorus availability in the response of soil nitrogen cycling, understory vegetation and arbuscular mycorrhizal inoculum potential to elevated nitrogen inputs. Water, Air, Soil Pollut. 147. $141-161$.

DEMIRBAS, A., 2006. Production and characterization of bio-chars from biomass via pyrolysis. Energy Sources, Part A. 28. 413-422.

Elmer, W. H. \& PignAtello, J. J., 2011. Effect of biochar amendments on mycorrhizal associations and Fusarium crown and root rot of asparagus in replant soils. Plant Disease. 95. 960-966.

Feigl, V., Anton, A., Uzinger, N. \& Gruiz, K., 2012. Red mud as a chemical stabilizer for soil contaminated with toxic metals. Water Air, Soil Pollut. 23. 12371247.

Fekete, I., Kotroczó, Zs., Varga, Cs., Hargitai, R., Townsend, K., Csányi, G. \& VÁRBIRÓ, G., 2012. Variability of organic matter inputs affects soil moisture and soil biological parameters in a European detritus manipulation experiment. Ecosystems. 15. 792-803.

Füzy, A., Biró, B., Tóth, T., Hildebrandt, J. \& Bothe, H. 2008. Drought, but not salinity determines the apparent effectiveness of halophytes colonized by arbuscular mycorrhizal fungi. J. Plant Physiol. 165. 1181-1192.

GAUnT, J. L. \& LeHMANN, J., 2008. Energy balance and emissions associated with biochar sequestration and pyrolysis bioenergy production. Environ. Sci. Technol. 42. 4152-4158.

Gaur, A. \& ADHOleyA, A., 2000. Effects of the particle size of soil-less substrates upon AM fungus inoculum production. Mycorrhiza. 10. 43-48.

Glaser, B., Haumaier, L., Guggenberger, G. \& Zech, W., 2001. The Terra Preta phenomenon: a model for sustainable agriculture in the humid tropics. Naturwissenschaften. 2001. 37-41. 
Graber, E. R., Harel, Y. M., Kolton, M., Cytryn, E., Silber, A., David, D. R., TSEChANSKY, L., Borenshtein, M. \& ElAD, Y., 2010. Biochar impact on development and productivity of pepper and tomato grown in fertigated soilless media. Plant Soil. 337. 481-496.

Gryndler, M., Larsen, J., Hrselova, C. H., Rezaccova, C. V., Gryndlerova, C. H. \& KUBA, C. J., 2006. Organic and mineral fertilization, respectively, increase and decrease the development of external mycelium of arbuscular mycorrhizal fungi in a longterm field experiment. Mycorrhiza. 16. 159-166.

Grossman, J. M., O’Neill B. E., Tsai, S. M., Liang, B., Neves, E., Lehmann, J. \& THIES, J. E., 2010. Amazonian anthrosols support similar microbial communities that differ distinctly from those extant in adjacent, unmodified soils of the same mineralogy. Microbial Ecol. 60. 192-205.

InTERnAtional ENERgy Agency, 2006. Annual Report - IEA Bioenergy. Task 34 Pyrolysis of Biomass.

JIN, H., 2010. Characterization of microbial life colonizing biochar and biocharamended soils. PhD Dissertation. Cornell University. Ithaca, NY.

Killham, K., 1985. Physiological determination of impact of environmental stress on the activity of microbial biomass. Environm. Pollut. Ser. A. 38. 283-294.

Kocsis T., WAss-Matics H., Kotroczó Zs. \& Biró B., 2015. A bioszén kedvező hatása a talaj pszikrofil- és mezofil csíraszámára. In: Proc. of „A hulladék-gazdálkodás legújabb fejlesztési lehetőségei” SZIE Zárókonferencia, (megjelenés alatt).

Kolb, S. E., Fermanich, K. J. \& Dornbush, M. E., 2009. Effect of charcoal quantity on microbial biomass and activity in temperate soils. Soil Sci. Soc. America J. 73. $1173-1181$.

Kotroczó Zs., Krakomperger Zs., Veres Zs., VasenszKi T. L., HalÁsz J., KonCZ G., PAPP M. \& TÓTH J. A., 2009. Talajlégzés vizsgálatok tartamhatású avarmanipulációs modellkísérletben. Természetvédelmi közl. 15. 328-337.

Kotroczó, Zs., Veres, Zs., Biró, B., Tóth, J. A. \& Fekete, I., 2014. Influence of temperature and organic matter content on soil respiration in a deciduous oak forest. Eurasian J. Soil Science 3. 303-310.

KumAR, S., JAIn, M. C. \& ChHONKAR, P. K., 1987. A note on the stimulation of biogas from cattle dung by addition of charcoal. Biol. Wastes. 20. 1209-1215.

LAIRD, D. A., 2008. The charcoal vision: A win-win-win scenario for simultaneously producing bioenergy, permanently sequestering carbon, while improving soil and water quality. Agronomy J. 100. 178-181.

LehmanN, J., 2007. A handful of Carbon. Nature. 447. 143-144.

LEHMANN, J. \& RONDON, M., 2006. Biochar soil management on highly weathered soils in the humid tropics. In: Biological Approaches to Sustainable Soil Systems. (Ed.: UPHOFF, N.) 517-530. CRCPress. Boca Raton, FL.

Lehmann, J., Silva, J. J. P., Steiner, C., Nehls, T., Zech, W. \& Glaser, B., 2003. Nutrient availability in archaeological anthrosol and ferralsol of Central Amazon basin: fertilizer, manure and charcoal amendments. Pl. Soil. 249. 343-357.

LehmanN, J., CZIMCZIK, C., LAIRD, D., \& SOHI, S. 2009. Stability of biochar in the soil. In: Biochar for Environmental Management: Science and Technology (Eds.: LEHMANN, J. \& JOSEPH, S.) 185-205. Earthscan. 
Lehmann, J., Rillig, M. C., Thies, J., Masiello, C. A., Hockaday, W. C. \& Crowley, D., 2011. Biochar effects on soil biota. Soil Biol. Biochem. 43. 18121836.

Liang, B., Lehmann, J., Solomon, D., Kinyangi, J., Grossman, J., O’Neill, B., SkJemstad, J. O., Thies, J., Luizão, F. J., Petersen, J., \& Neves, E. G., 2006. Black carbon increases cation exchange capacity in soils. Soil Sci. Soc. America J. 70. 1719-1730.

Liang, B., Lehmann, J., Sohi, S. P., Thies, J. E., O’Neill, B., Trujillo, L., Gaunt, J., Solomon, D., Grossman, J., Neves, E. G. \& Luizão, F. J., 2010. Black carbon affects the cycling of non-black carbon in soil. Org. Geochem. 41. 206-213.

Libisch, B., French, H. K., HARTnik, T., Anton, A. \& Biró, B., 2012. Laboratory scale evaluation of selected remediation techniques for propylene-glycol based aircraft deicing fluids. Environ. Technol. 33. 717-724.

Major, J., Rondon, M., Molina, D., Susan, J., Lehmann, R. \& LehmanN, J., 2010. Maize yield and nutrition during 4 years after biochar application to a Colombian savanna oxisol. Plant Soil. 333. 117-128.

Makoto, K., TAmai, Y., KIM Y. S. \& Koike, T., 2010. Buried charcoal layer and ectomycorrhizae cooperatively promote the growth of Larix gmelinii seedlings. Plant and Soil. 327. 143-152.

O’Neill, B., Grossman, J., Tsa, M. T., Gomes, J. E., Lehmann, J., Peterson, J., Neves, E. \& ThIES, J. E., 2009. Bacterial community composition in Brazilian Anthrosols and adjacent soils characterized using culturing and molecular identification. Microbial Ecol. 58. 23-35.

OGAwA, M. \& OKIMORI, Y., 2010. Pioneering works in biochar research, Japan Australian J. Soil Res. 48. 489-500.

Oguntunde, P. G., Fosu, M., Ajayi, A. E. \& VAN DE Giesen, N., 2004. Effects of charcoal production on maize yield, chemical properties and texture of soil. Biol. Fertil. Soils. 39. 295-299.

PIETIKÄINEN, J., KIIKKILÄ, O. \& FrITZE, H., 2000. Charcoal as habitat for microbes and its effects on microbial community of underlying humus. Oikos, 89. 231-242.

RÉKÁSI M. \& UzINGER N., 2015. Bioszén felhasználásának lehetőségei a talaj tápanyagutánpótlásában. Agrokémia és Talajtan. 64. (1) (megjelenés alatt)

Rillig, M. C., Wagner, M., Salem, M., Antunes, P. M., George, C., Ramke, H. G., TitiRici, M. M. \& ANTONIETTI, M., 2010. Material derived from hydrothermal carbonization: effects on plant growth and AMF. Appl. Soil Ecol. 45. 238-242.

Rousk, J., BroOKes, P. C. \& BÅATH, E., 2009. Contrasting soil pH effects on fungal and bacterial growth suggest functional redundancy in carbon mineralization. Appl. Environm. Microbiol. 75. 1589-1596.

Rousk, J., BÅ̊tTh, E., Brookes, P. C., Lauber, C. L., Lozupone, C., Caporaso, J. G., KNight, R. \& FiERER, N., 2010. Soil bacterial and fungal communities across a pH gradient in an arable soil. The ISME. 4. 134-151.

Schmidt, B., Domonkos, M., Şumalan, R. \& Biró, B., 2010. Suppression of arbuscular mycorrhiza's development by high concentrations of phosphorous at Tagetes patula L. Res. J. Agricult. Sci. 44. 156-162.

Singh, B. P., Hatton, B. J., Singh, B., Cowie, A. L. \& Kathuria, A., 2010. Influence of biochars on nitrous oxide emission and nitrogen leaching from two contrasting soils. J. Environ. Quality. 39. 1224-1235. 
Sohi, S., Lopez-CAPel, E., Krull, E., \& Bol, R., 2009. Biochar, climate change and soil: a review to guide future research. CSIRO Land and Water Sci. Report.

Solaiman, Z. M., Blackwell, P., ABbott, L. K. \& Storer, P., 2010. Direct and residual effect of biochar application on mycorrhizal colonization, growth and nutrition of wheat. Austral. J. Soil Res. 48. 546-554.

Solomon, D., Lehmann, J., Thies, J., SchäFer, T., LiAng, B., Kinyangi, J., NeVES, E., Petersen, J., Luizo, F., \& SkJEMStad, J., 2007. Molecular signature and sources of biochemical recalcitrance of organic C in Amazonian Dark Earths. Geochim. Cosmochim. Acta. 71. 2285-2298.

SPOKAS, K. A. \& REICOSKY, D. C., 2009. Impacts of sixteen different biochars on soil greenhouse gas production. Annals Environ. Sci. 3. 179-193.

Steiner, C., TeixeirA, W. G., Lehmann, J. \& Zech, W., 2004. Microbial response to charcoal amendments of highly weathered soils and Amazonian Dark Earths in Central Amazonia e preliminary results. In: Amazonian Dark Earths: Explorations in Time and Space. (Eds.: GlaSER, B. \& WoOdS, W. I.) 195-212. Springer. Berlin, Germany.

SteINER, C., GARCIA, M. \& ZECH, W., 2009. Effects of charcoal as slow release nutrient carrier on NPK dynamics and soil microbial population: pot experiments with ferralsol substrate. In: Amazonian Dark Earths: Wim Sombroek's Vision. (Eds.: WoODS W. I., et al.) 325-338. Springer. Berlin.

SzILI-KovÁCS T., KÁTAI J. \& TAKÁCS T., 2011a. Mikrobiológiai indikátorok alkalmazása a talajminőség értékelésében. 1. Agrokémia és Talajtan. 60. 273-286.

SzILI-KovÁCS, T., SzABÓ, R., HALASSY, M. \& TÖRÖK, K., 2011b. Restoration of a sandy grassland by the application of various carbon sources promoting the immobilization of soil nitrogen. Agrokémia és Talajtan. 60. 255-266.

Tóth., J. A., NAgy, P. T., Krakomperger, Zs., Veres, Zs., Kotroczó, Zs., Kincses, S., FeKete, I., PAPP, M., MÉszÁros, I., VikTor, O., 2013. The effects of climate change on element content and soil pH (Síkfökút DIRT project, Northern Hungary). In: The Carpathians: Integrating nature and society towards sustainability. Environm. (Eds.: KozaK, J., OSTAPOWICZ K.., Bytnerowicz A., WyzGa B.,) $77-$ 88. Sci. Engineer. Springer-Verlag Berlin Heidelberg.

Treseder, K. K. \& Allen, M. F., 2002. Direct nitrogen and phosphorus limitation of arbuscular mycorrhizal fungi: a model and field test. New Phytol. 155. 507-515.

Verheijen, F. G. A., Jones, R. J. A., Rickson, R. J. \& Smith, C. J., 2009. Tolerable versus actual soil erosion rates in Europe. Earth-Sci. Reviews. 94. 23-38.

WArdle, D. A., NilsSon, M. C. \& ZaCKRISSON, O., 2008. Fire-derived charcoal causes loss of forest humus. Science. 320. 629-629.

WARnock, D. D., Lehmann, J., KuYPer, T. W., \& Rillig, M. C., 2007. Mycorrhizal responses to biochar in soil: concepts and mechanisms. Plant Soil. 300. 9-20.

Warnock, D. D., Mummey, D. L., McBride, B., Major, J., Lehmann, J. \& Rillig, M. C., 2010. Influences of non-herbaceous biochar on arbuscular mycorrhizal fungal abundances in roots and soils: results from growth-chamber and field experiments. Appl. Soil Ecol. 46. 450-456.

Zackrisson, O., Nilsson, M. C. \& WARdLe, D. A., 1996. Key ecological function of charcoal from wildfire in the boreal forest. Oikos. 77. 10-19. 
Zimmerman, A. R., GAO, B. \& Mi-Youn, A., 2011. Positive and negative carbon mineralization priming effects among a variety of biochar-amended soils. Soil Biol. Biochem. 43. 1-11.

Érkezett: 2015. január 7. 


\title{
Effect of biochar on the soil-plant-microbe system: advantages and concerns - A Review
}

\author{
T. Kocsis and B. BIRÓ \\ Corvinus University of Budapest, Faculty of Horticulture, Department of Soil Science and Water \\ Management
}

\section{Summary}

Data in the literature suggest that biochar products could be applied on a wide scale to influence soil-plant-microbe interactions. Biochar may improve physical and chemical soil properties, soil water retention, clay and organic matter contents, $\mathrm{pH}$ levels, $\mathrm{N}$ and $\mathrm{P}$ availability, quantities of other meso- and micro-nutrients and, due to its high porosity, soil aeration and the content and ratio of oxygen.

The positive effect on plant nutrition may be manifested both directly and indirectly. The more efficient growth of microorganisms in biochar-treated soils is well documented. Biochar protects the soil surface from drying out, provides a more oxygen-rich environment and supplies the micro-organisms with adsorbed organic materials, improving the growth of both bacteria and fungi. In addition to soil properties, a higher microbial population is also promoted by higher temperature and optimal $\mathrm{pH}$ levels. Publications on the integration of biochar into crop production technologies report yield increases, at least in the short term. However, the quantities and activity of the microsymbiont bacteria and P-mobilizing mycorrhizal fungi that are beneficial for crop production exhibit strong dose- and product-dependence. The efficiency of symbiosis may deteriorate in the case of environmental stress. The application of unnecessarily high rates is a cause for concern due to their nutritional and/or water-binding properties, particularly as this may lead to the multiplication of soil-borne pathogenic microorganisms. Biochar could therefore be a valuable soil amendment, but it can only be exploited safely if applied with caution after the detailed physical, chemical and biological analysis of the soil.

Table 1. Fate of initial feedstock mass as the result of different pyrolysis processes (IEA 2006). (1) Method of pyrolysis. (2) Liquid, biofuel. (3) Solid, biochar. (4) Gaseous, biogas. a) Rapid pyrolysis at moderate temperature for a short time, b) Slow pyrolysis at low temperature using hot steam for a long period, c) Slow heating at low temperature for a long period, (d) Gasification at high temperature for a long period.

Table 2. Main physico-chemical properties of the Columbian soil "Terra Preta" and of neighbouring control soils (data from SOLOMON et al. 2007, LiANG et al. 2006). (1) Location. (2) Soil. (3) Fertile layer, cm. (4) Age. (5) Clay.

Table 3. Properties of biochar-treated soil and its effect of the main symbiotic microbial groups (data from LEHMANN et al., 2011). (1) Mechanism, effect. (2) Bacteria. (3) Fungi. Note: + Positive effect, - negative effect, 0 no change, ? unknown reaction.

Figure 1. Effect of biochar on maize grain yields $(n=3)$. Yield increases are expressed as a $\%$, different letters within a column indicate significant differences $(p<0.05)$ between means (MAJOR et al., 2010). 